\title{
Genetic Polymorphisms of the Serotonin Transporter, but Not the 2a Receptor or Nitric Oxide Synthetase, Are Associated with Pulmonary Hypertension in Chronic Obstructive Pulmonary Disease
}

\author{
Silvia Ulrich Martin Hersberger Manuel Fischler Yvonne Nussbaumer-Ochsner \\ Ursula Treder Erich W. Russi Rudolf Speich \\ Clinics of Internal Medicine and Pulmonology, University Hospital Zürich, Zürich, Switzerland
}

\section{Key Words}

Chronic obstructive pulmonary disease $\cdot$ Genetic •

Polymorphism • Pulmonary hypertension · Serotonin •

Serotonin transporter

\begin{abstract}
Background: Pulmonary hypertension (PH) is prognostically important in chronic obstructive pulmonary disease (COPD). Since PH only weakly correlates with hypoxemia, other factors must play a role. Objective: To investigate whether polymorphisms of the serotonin transporter (5HTT), serotonin-2a receptor (5HTR2a) and endothelial nitric oxide synthetase (eNOS) are related to PH in COPD. Methods: In 59 COPD patients who underwent right heart catheterization, 6-min walking distance, NYHA functional class, pulmonary function tests, blood gases and 5HTT, 5HTR2a and eNOS (4ab and T298C) polymorphisms were determined. Results: Forty-nine COPD patients in NYHA functional class III-IV were included. Ten were excluded due to comorbid causes of PH (mainly chronic thromboembolic). PH (mPAP $\geq 25 \mathrm{~mm}$ $\mathrm{Hg}$ ) was present in $55 \%$ and usually mild, but out of proportion (mPAP $\geq 40 \mathrm{~mm} \mathrm{Hg}$ ) in $12 \%$. Patients with PH had significantly higher frequencies of the 5HTT-L-allele (52\%) com-
\end{abstract}

pared to individuals without PH (36\%), and LL homozygote patients had more severe $\mathrm{PH}$. In patients with out-of-proportion $\mathrm{PH}$, the L-allelic frequency was even $75 \%$. We found no association of 5HTR2a and eNOS polymorphism with $\mathrm{PH}$ in COPD. Conclusions: In this COPD cohort we confirm that PH is frequent and usually mild, but out of proportion in a subgroup. We found a significant association of the L-allelic variant of 5HTT with PH overall and especially in out-of-proportion $\mathrm{PH}$. These findings may point towards a role of the serotonin system in COPD-PH and warrant further studies.

Copyright $\odot 2009$ S. Karger AG, Basel

\section{Introduction}

Chronic obstructive pulmonary disease (COPD) is one of the leading causes of morbidity in the Western world, mainly due to cigarette smoking. COPD leads to pulmonary hypertension $(\mathrm{PH})$ in some subjects, but not in others [1]. The development of PH in COPD has been mainly attributed to alveolar hypoxia, which leads to pulmonary vasoconstriction, vessel remodeling and increased pulmonary vascular resistance [1]. Long-term oxygen therapy improves the prognosis of patients with

\section{KARGER}

Fax +4161306 1234 E-Mail karger@karger.ch www.karger.com
(C) 2009 S. Karger AG, Basel

0025-7931/10/0794-0288\$26.00/0

Accessible online at:

www.karger.com/res
Silvia Ulrich, MD

Internal Medicine Clinic, University Hospital Zürich

Rämistrasse 100

CH-8091 Zürich (Switzerland)

Tel. +41 4425543 62, Fax +41 4425544 15, E-Mail silvia.ulrich@usz.ch 
COPD and stabilizes pulmonary artery pressure, and $\mathrm{PH}$ is the strongest prognostic factor for COPD patients under long-term oxygen therapy, independent of the severities of airflow limitation or hypoxemia [2]. But not every hypoxemic COPD patient develops $\mathrm{PH}$ and the degree of PH only weakly correlates with hypoxemia; therefore, other predisposing factors must be postulated, most probably genetic ones. In most COPD patients, $\mathrm{PH}$ is mild [3, 4], however, a subgroup develops severe and rapidly progressive $\mathrm{PH}$ resembling other forms of vasoproliferative pulmonary vessel disease, such as idiopathic pulmonary arterial hypertension (PAH) $[5,6]$. Recognition of a genetic susceptibility to $\mathrm{PH}$ in COPD patients would have relevant implications for the pathogenetic understanding, and potentially early diagnosis and treatment. Important factors contributing to the pathogenesis of $\mathrm{PH}$ in various diseases are nitric oxide (NO), serotonin, endothelin and prostaglandins.

Polymorphism of the serotonin transporter (5HTT) determined the severity of $\mathrm{PH}$ in hypoxemic French and British patients with COPD [7]. However, this association could not be found in idiopathic or familial PAH [8]. Serotonin leads to pulmonary vasoconstriction via its $2 \mathrm{a}$ and $\mathrm{b}$ receptors (5HTR $2 \mathrm{a}$ and $\mathrm{b}$ ). The T102C polymorphism of 5HTR2a has been associated with arterial hypertension, myocardial infarction and psychiatric disorders $[9,10]$, but has not been investigated in $\mathrm{PH}$. NO plays a key role in systemic and pulmonary endothelial dysfunction [11]. Polymorphism in the endothelial NO synthetase (eNOS) has been associated with the development of arteriosclerosis and high altitude pulmonary edema in Japanese and Indian populations [12, 13]. However, eNOS polymorphisms were not related to pulmonary artery pressures at altitude in Caucasians [14].

The aim of the present study was to investigate the association of 5HTT, 5HTR2a and eNOS polymorphisms with $\mathrm{PH}$ confirmed by right heart catheterization (RHC) in COPD patients.

\section{Material and Methods}

\section{Study Subjects}

Outpatients with COPD diagnosed according to the Global Initiative for Chronic Obstructive Lung Disease (GOLD) guidelines [15-17] who had RHC and pulmonary function testing (PFT) within 2 weeks were asked to participate upon written informed consent. Patients were scheduled for RHC according to their treating physicians' judgment (mostly physicians not involved in the study inclusion) mainly because they had severe exertional dyspnea (often more than expected from their PFT) and/or before lung volume reduction surgery. The study was approved by the local ethics review board. Fifty-nine COPD patients ( 25 females) at a mean age of $68 \pm 8$ years were assessed. Ten patients were excluded because a thorough investigation revealed other reasons for PH: 6 patients had chronic thromboembolic $\mathrm{PH}$ confirmed by pulmonary angiography, 3 patients had postcapillary $\mathrm{PH}$ due to left heart disease and 1 patient was diagnosed with scleroderma. Thus, data from 49 COPD patients were analyzed.

\section{Study Assessments}

Patients willing to participate had their blood lymphocytes genetically analyzed. Demographics including age, sex, height, weight, body mass index, smoking history, drug use, NYHA class and 6-min walking distance were obtained, all within 2 weeks of RHC and PFT. Swan-Ganz catheters were placed by standard techniques and cardiac output was assessed by thermodilution (Baxter/Edwards, Deerfield, Ill., USA). Hemodynamic data from RHC (mean pulmonary artery pressure, mPAP; cardiac index; pulmonary vascular resistance), arterial and mixed venous blood analysis (oxygen and carbon dioxide pressures and saturation), and data from PFT (forced expiratory volume in $1 \mathrm{~s}$; forced vital capacity; total lung capacity; residual volume; single breath transfer factor for carbon monoxide; all given as percent predicted) were noted. We defined mPAP according to the WHO as $\geq 25$ $\mathrm{mm} \mathrm{Hg}$ [18] and out-of-proportion PH in COPD as mPAP $>40$ mm Hg [19].

Genetic Analysis

EDTA-supplemented blood samples were extracted with the QIAamp ${ }^{\circledR}$ DNA Mini Kit (Qiagen AG, Basel, Switzerland). Primers were designed with the OLIGO 4.0 software (Medprobe, Oslo, Norway) and purchased from Microsynth (Balgach, Switzerland).

For detection of the Glu298Asp polymorphism in eNOS, a 25$\mu l$ tetraprimer PCR reaction was developed using the Amplitaq Gold ${ }^{\mathrm{TM}}$ System (Perkin-Elmer Corp., Hünenberg, Switzerland); $0.1 \mu \mathrm{M}$ of primers NOSU6749 (5'-AGGGGAGCCTCGGTGAGATAAAG-3') and NOSL7115 (5'-GCAGGCCCTTCTTGAGAGG-3'), as well as $0.14 \mu \mathrm{M}$ of primers NOSU6986G (5'-TGCAGGCCCCAGATGAG-3') and NOSL7002T (5'-AAGGAAGAGTTCTGGGGGA-3') were added to the standard amplification mixture with $100 \mathrm{ng}$ genomic DNA and the following cycling parameters were used: $10 \mathrm{~min}$ at $94^{\circ} \mathrm{C}, 10 \mathrm{cycles}$ (first set) of $94^{\circ} \mathrm{C}$ for $30 \mathrm{~s}, 60^{\circ} \mathrm{C}$ for $30 \mathrm{~s}, 72^{\circ} \mathrm{C}$ for $60 \mathrm{~s}, 25$ cycles (second set) of $94^{\circ} \mathrm{C}$ for $30 \mathrm{~s}, 53^{\circ} \mathrm{C}$ for $30 \mathrm{~s}, 72^{\circ} \mathrm{C}$ for $60 \mathrm{~s}$, and a final extension of $7 \mathrm{~min}$ at $72^{\circ} \mathrm{C}[20,21]$.

Genotyping of the 27-bp repeat in intron 4 of the eNOS gene $($ eNOS4a/b) was performed according to Wang et al. [22] with minor modifications. The allele with 4 repeats was designated $4 \mathrm{a}$ and the longer allele with 5 repeats was designated $4 \mathrm{~b}$. The 44 -bp insertion/deletion polymorphism in 5HTT was analyzed using $0.5 \mu \mathrm{M}$ of primers $5 \mathrm{HTT} \mathrm{U}\left(5^{\prime}\right.$-CTC TGA ATG CCA GCA CCT AAC- $3^{\prime}$ ) and 5HTT L (5'-GGA TTC TGG TGC CAC CTA GAC$\left.3^{\prime}\right)$ as well as the Expand Long Template Kit from Roche Molecular Biochemicals (Rotkreuz, Switzerland). PCR resulted in a long amplification product of $457 \mathrm{bp}$ and in a short amplification product of $414 \mathrm{bp}$ for the 2 alleles which were separated on agarose gels. 
Table 1. Patient characteristics

\begin{tabular}{|c|c|}
\hline & Numbers \\
\hline Total number of patients & $49(100)$ \\
\hline Females/males & $18 / 31(37 / 63)$ \\
\hline Age, years & $68 \pm 8$ \\
\hline Body mass index & $24 \pm 4$ \\
\hline Smokers & $44(90)$ \\
\hline Current/past & $5 / 39(11 / 79)$ \\
\hline Mean pack years smoked & $52 \pm 30$ \\
\hline NYHA functional class III-IV & $21 / 28(43 / 57)$ \\
\hline 6-min walking distance, $\mathrm{m}$ & $298 \pm 125$ \\
\hline COPD severity by GOLD stage I/II/III/IV & $\begin{array}{c}3 / 12 / 20 / 14 \\
(6 / 25 / 41 / 28)\end{array}$ \\
\hline \multicolumn{2}{|l|}{ Pulmonary function tests ${ }^{1}$} \\
\hline $\mathrm{FEV}_{1}, \%$ predicted & $41 \pm 21$ \\
\hline FVC, $\%$ predicted & $74 \pm 25$ \\
\hline $\mathrm{FEV}_{1} / \mathrm{FVC}$ ratio & $0.48 \pm 0.12$ \\
\hline Total lung capacity, \% predicted & $120 \pm 25$ \\
\hline Residual volume, $\%$ predicted & $196 \pm 74$ \\
\hline \multicolumn{2}{|l|}{ Carbon monoxide diffusion capacity } \\
\hline$\%$ predicted & $42 \pm 22$ \\
\hline \multicolumn{2}{|l|}{ Pulmonary hemodynamics (invasive) } \\
\hline $\mathrm{mPAP}, \mathrm{mm} \mathrm{Hg}$ & $28 \pm 11$ \\
\hline Cardiac index, $1 / \mathrm{min} / \mathrm{m}^{2}$ & $2.5 \pm 0.6$ \\
\hline Pulmonary vascular resistance, $\mathrm{dyn} \cdot \mathrm{sec} \cdot \mathrm{m}^{-5}$ & $378 \pm 222$ \\
\hline Right atrial pressure, $\mathrm{mm} \mathrm{Hg}$ & $6.5 \pm 5$ \\
\hline Pulmonary artery occlusion pressure, $\mathrm{mm} \mathrm{Hg}$ & $10 \pm 4$ \\
\hline \multicolumn{2}{|c|}{ Blood gas analysis } \\
\hline Arterial oxygen saturation, $\%$ & $90 \pm 6$ \\
\hline Arterial oxygen partial pressure, $\mathrm{kPa}$ & $7.9 \pm 1$ \\
\hline Arterial carbon dioxide partial pressure, $\mathrm{kPa}$ & $5.4 \pm 0.8$ \\
\hline Mixed venous oxygen saturation, $\%$ & $64 \pm 8$ \\
\hline
\end{tabular}

Figures in parentheses are percentages. $\mathrm{FEV}_{1}=$ Forced expiratory volume in $1 \mathrm{~s} ; \mathrm{FVC}=$ forced vital capacity.

${ }^{1}$ Percent predicted by the European Society of Coal and Steel.

For detection of the T102C polymorphism in the HTR2A gene, a LightCycler assay was developed. Four oligonucleotides were added to the LightCycler DNA Master Hybridization Probes mixture (Roche Molecular Biochemicals) at the following final concentrations: $0.5 \mu \mathrm{M}$ of HTR2A U135 (5'-CTG GCT TAG ACA TGG ATA TT-3') and HTR2A L336 (5'-ATG AAG TAA GGA GAG ACA CG-3'), $0.4 \mu \mathrm{M}$ of Anchor T102C (5'-LCRed640-TTA CTG TAG AGC CTG GTG TCA TCA TTT-ph-3') and $0.2 \mu \mathrm{M}$ of Sensor T102C (5'-GTT AGC TTC TCC AGA GTT AAA GTC-FL$\left.3^{\prime}\right)$. The final magnesium concentration was $2 \mathrm{mmol} / \mathrm{l}$, and 100 ng DNA were added in a total volume of $20 \mu$ l. The following temperature protocol was applied: $95^{\circ} \mathrm{C}$ for $45 \mathrm{~s}$, followed by 50 cycles of $95^{\circ} \mathrm{C}$ for $0 \mathrm{~s}, 58^{\circ} \mathrm{C}$ for $10 \mathrm{~s}$, and $72^{\circ} \mathrm{C}$ for $9 \mathrm{~s}$ with a ramping rate of $20^{\circ} \mathrm{C} / \mathrm{s}$. Melting curve analysis was performed from $40^{\circ} \mathrm{C}$ to $85^{\circ} \mathrm{C}$ at a linear rate of $0.1^{\circ} \mathrm{C} / \mathrm{s}[23]$.

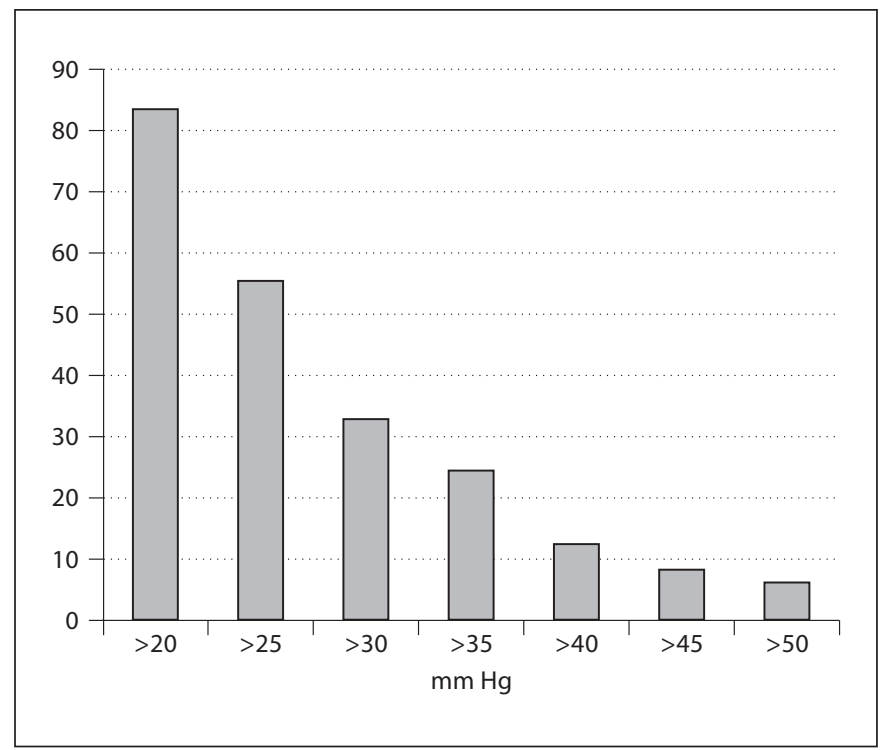

Fig. 1. Percent of COPD patients with mPAP above different thresholds $(n=49)$.

\section{Statistical Analysis}

Results are expressed as means $\pm \mathrm{SD}$. The Mann-Whitney U test and analysis of variance were used to compare means and Fisher's exact test was applied to compare frequencies between groups. Differences showing $\mathrm{p}<0.05$ were considered statistically significant. Statistical analysis was performed using SPSS version 15.0 software package.

\section{Results}

\section{Patients' Characteristics and Clinical Presentation}

The baseline characteristics of the 49 patients included are shown in table 1. All patients were in NYHA classes III and IV and were severely exercise limited (mean 6min walking distance $298 \pm 125 \mathrm{~m}$ ). COPD severity according to GOLD varied, all but 3 were moderately to severely affected. Most patients had a history of cigarette smoking. PH was present in 27 (55\%) of the patients. RHC was performed during a stable condition without any signs for COPD exacerbation and on room air. Overall, PH was usually mild, however, 6 (12\%) patients had outof-proportion $\mathrm{PH}$ (fig. 1). Patients with $\mathrm{PH}$ had less severe airway obstruction and lung hyperinflation compared to patients without $\mathrm{PH}$ (table 2). We found a weak correlation between the degrees of hypoxemia and PH (fig. 2), but an even weaker inverse correlation between the severities of airway obstruction and $\mathrm{PH}$. 
Table 2. Characteristics of COPD patients with and without $\mathrm{PH}$ (mPAP $\geq 25 \mathrm{~mm} \mathrm{Hg}$ )

\begin{tabular}{|c|c|c|}
\hline & Without PH & With PH \\
\hline Total number of patients & $22(45)$ & $27(55)$ \\
\hline Females/males & $5 / 17(23 / 77)$ & $13 / 14(48 / 52)$ \\
\hline Age, years & $66 \pm 7$ & $70 \pm 8$ \\
\hline Body mass index & $24 \pm 4$ & $24 \pm 5$ \\
\hline Smokers & $21(95)$ & $22(81)$ \\
\hline Current/past & $1 / 20(5 / 95)$ & $4 / 18(18 / 78)$ \\
\hline Mean pack years smoked & $55 \pm 28$ & $49 \pm 33$ \\
\hline NYHA functional class III /IV & $11 / 11(50 / 50)$ & $10 / 17(37 / 63)$ \\
\hline 6-minute walking distance, $\mathrm{m}$ & $268 \pm 129$ & $323 \pm 118$ \\
\hline COPD severity by GOLD stage I/II/III/IV & $0 / 2 / 11 / 9(0 / 9 / 50 / 41)$ & $3 / 10 / 9 / 5(11 / 40 / 33 / 16)$ \\
\hline \multicolumn{3}{|l|}{ Pulmonary function tests 1} \\
\hline $\mathrm{FEV}_{1}, \%$ predicted & $30 \pm 11$ & $51 \pm 23^{* *}$ \\
\hline FVC, $\%$ predicted & $66 \pm 22$ & $81 \pm 25^{*}$ \\
\hline $\mathrm{FEV}_{1} / \mathrm{FVC}$ ratio & $0.46 \pm 0.12$ & $0.50 \pm 0.11$ \\
\hline Total lung capacity, $\%$ predicted & $128 \pm 23$ & $113 \pm 24^{*}$ \\
\hline Residual volume, $\%$ predicted & $228 \pm 63$ & $167 \pm 71^{* *}$ \\
\hline Carbon monoxide diffusion capacity, \% predicted & $39 \pm 15$ & $44 \pm 27$ \\
\hline \multicolumn{3}{|l|}{ Pulmonary hemodynamics } \\
\hline $\mathrm{mPAP}, \mathrm{mm} \mathrm{Hg}$ & $19 \pm 4$ & $35 \pm 10^{* *}$ \\
\hline Cardiac index, $1 / \mathrm{min} / \mathrm{m}^{2}$ & $2.5 \pm 0.5$ & $2.5 \pm 0.7$ \\
\hline Pulmonary vascular resistance, $\mathrm{dyn} \cdot \mathrm{sec} \cdot \mathrm{m}^{-5}$ & $238 \pm 98$ & $473 \pm 223^{* *}$ \\
\hline Right atrial pressure, $\mathrm{mm} \mathrm{Hg}$ & $5 \pm 4$ & $8 \pm 5$ \\
\hline Pulmonary artery occlusion pressure, $\mathrm{mm} \mathrm{Hg}$ & $9 \pm 4$ & $10 \pm 4$ \\
\hline \multicolumn{3}{|l|}{ Blood gas analysis } \\
\hline Arterial oxygen saturation, $\%$ & $92 \pm 4$ & $88 \pm 7$ \\
\hline Arterial oxygen partial pressure, $\mathrm{kPa}$ & $8.1 \pm 1.0$ & $7.6 \pm 1.1$ \\
\hline Arterial carbon dioxide partial pressure, $\mathrm{kPa}$ & $5.4 \pm 0.8$ & $5.4 \pm 0.8$ \\
\hline Mixed venous oxygen saturation, $\%$ & $66 \pm 5$ & $63 \pm 9$ \\
\hline
\end{tabular}

Data given as numbers (\%) or means $\pm \mathrm{SD} .{ }^{*} \mathrm{p}<0.05 ;{ }^{* *} \mathrm{p}<0.01$.

${ }^{1}$ Normal values obtained from the European Society of Coal and Steel.

Table 3. Frequencies of the serotonin transporter polymorphisms in COPD patients (overall and by the presence of $\mathrm{PH}$ )

\begin{tabular}{llrllll}
\hline COPD patients & \multicolumn{2}{l}{ Genotypes } & & & \multicolumn{2}{l}{$\begin{array}{l}\text { Allele } \\
\text { frequencies, \% }\end{array}$} \\
\cline { 2 - 3 } \cline { 5 - 7 } & SS & SL & LL & & S & L \\
\hline Overall $(\mathrm{n}=49)$ & $13(27)$ & $28(57)$ & $8(16)$ & & 63 & 37 \\
No PH $(\mathrm{n}=22)$ & $8(36)$ & $12(55)$ & $2(9)$ & & 64 & 36 \\
With PH $(\mathrm{n}=27)$ & $5(19)$ & $16(59)$ & $6(22)$ & & 48 & $52^{*}$ \\
Out-of-proportion PH $(\mathrm{n}=6)$ & 0 & $3(50)$ & $3(50)$ & & 25 & $75^{* *}$ \\
\hline
\end{tabular}

Figures in parentheses are percentages. ${ }^{*} \mathrm{p}<0.05$ for COPD with versus without $\mathrm{PH} ;{ }^{*} \mathrm{p}<0.05$ for out-ofproportion $\mathrm{PH}$ (defined as $\mathrm{mPAP}>40 \mathrm{~mm} \mathrm{Hg}$ ) versus without $\mathrm{PH}$ and/or all others. 


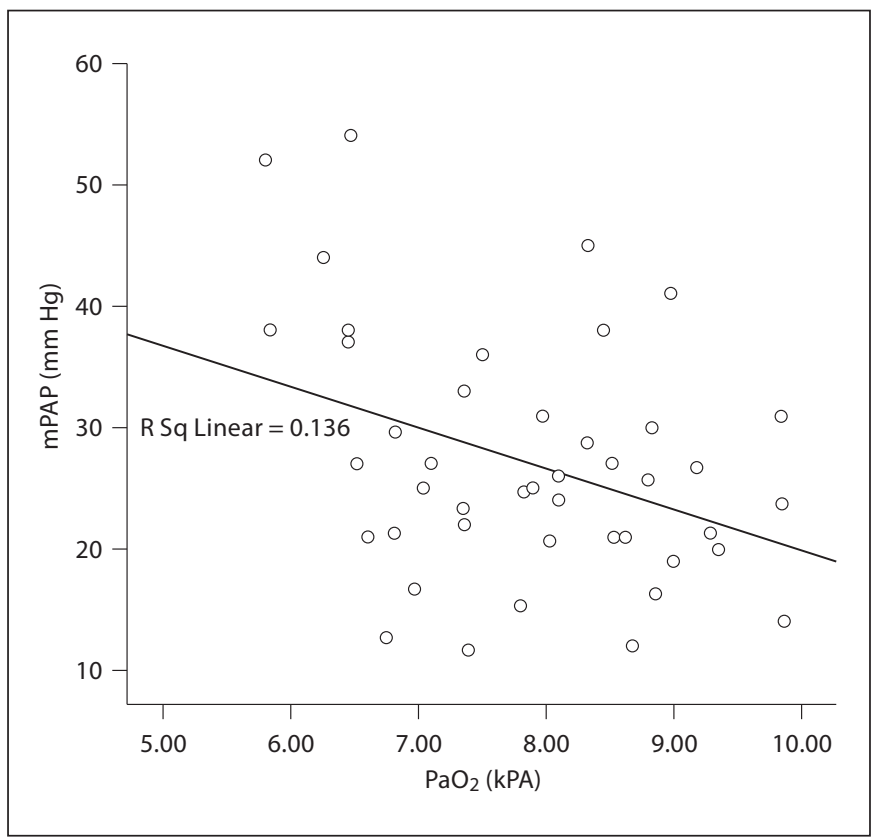

Fig. 2. mPAP plotted against arterial oxygen pressure $\left(\mathrm{PaO}_{2}\right)$.

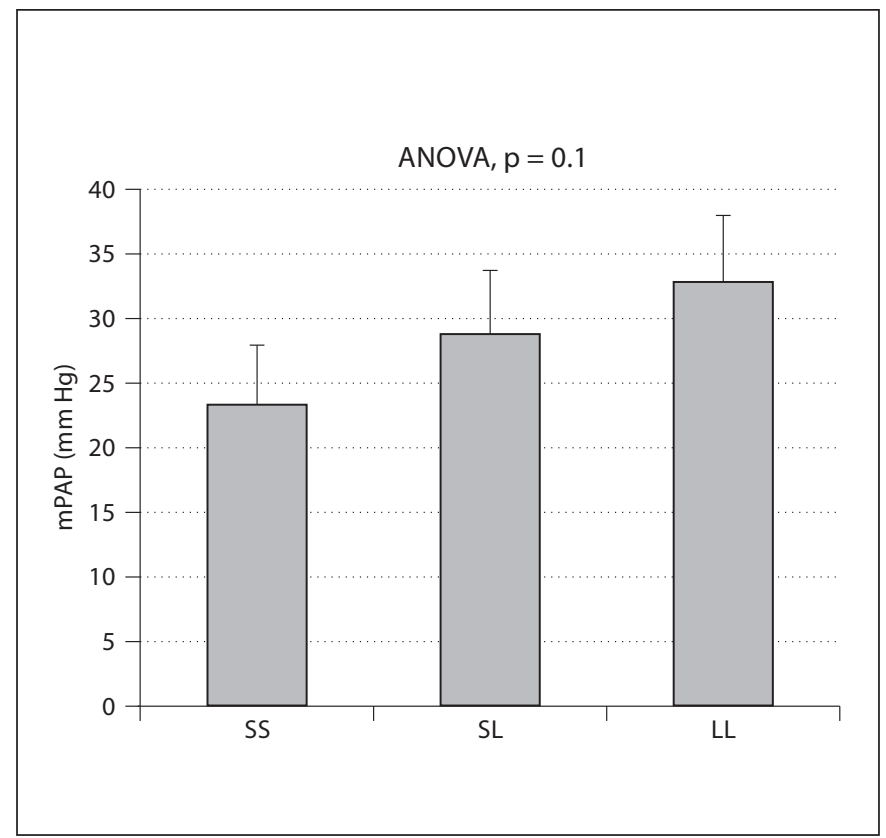

Fig. 3. $\mathrm{mPAP}(\mathrm{mm} \mathrm{Hg})$ by $5 \mathrm{HTT}$ allelic variants.

Table 4. Frequencies of the tested serotonin-2a receptor and NO synthetase polymorphisms in COPD patients (overall and by the presence of $\mathrm{PH}$ )

\begin{tabular}{|c|c|c|c|c|c|c|}
\hline \multirow[t]{2}{*}{ COPD patients } & \multirow{2}{*}{$\begin{array}{l}\begin{array}{l}\text { Type of } \\
\text { polymorphism }\end{array} \\
5 \text { HTR2a }\end{array}$} & \multicolumn{3}{|c|}{ Genotypes } & \multicolumn{2}{|c|}{$\begin{array}{l}\text { Allele } \\
\text { frequencies, \% }\end{array}$} \\
\hline & & TT & TC & $\mathrm{CC}$ & $\mathrm{T}$ & $\mathrm{C}$ \\
\hline Overall $(\mathrm{n}=49)$ & & $8(16)$ & $30(61)$ & $11(23)$ & 44 & 56 \\
\hline No PH $(n=22)$ & & $5(23)$ & $12(54)$ & $5(23)$ & 50 & 50 \\
\hline \multirow[t]{2}{*}{ With PH $(\mathrm{n}=27)$} & & $3(11)$ & $18(67)$ & $6(22)$ & 48 & 52 \\
\hline & eNOS4a/b & $\mathrm{bb}$ & $\mathrm{ab}$ & aa & $\mathrm{b}$ & $\mathrm{a}$ \\
\hline Overall $(\mathrm{n}=49)$ & & $31(63)$ & $17(35)$ & $1(2)$ & 84 & 16 \\
\hline No PH $(n=22)$ & & $14(64)$ & $8(36)$ & 0 & 82 & 18 \\
\hline \multirow[t]{2}{*}{ With PH $(n=27)$} & & $17(63)$ & $9(33)$ & $1(4)$ & 80 & 20 \\
\hline & eNOS298 & Glu/Glu & Glu/Asp & Asp/Asp & Glu & Asp \\
\hline Overall $(\mathrm{n}=49)$ & & $25(51)$ & $22(45)$ & $2(4)$ & 78 & 22 \\
\hline No PH $(n=22)$ & & $11(50)$ & $9(41)$ & $2(9)$ & 70 & 30 \\
\hline With PH $(\mathrm{n}=27)$ & & $14(52)$ & $13(48)$ & 0 & 76 & 24 \\
\hline
\end{tabular}

Figures in parentheses are percentages. 


\section{Genetic Analysis}

Frequencies of the 5HTT, 5HTR2a and eNOS $(4 \mathrm{a} / \mathrm{b}$ and 298) genotypes are shown in table 3 and 4 for all COPD patients separated by the presence of $\mathrm{PH}$. COPD patients with $\mathrm{PH}$ were significantly more likely to carry the LL genotypes of the 5HTT gene compared to COPD without $\mathrm{PH}(\mathrm{p}=0.03)$. Three of the 6 patients with $\mathrm{PH}$ $>40 \mathrm{~mm} \mathrm{Hg}$ were homozygote for the LL variant and 3 heterozygote, the allelic frequency of the L variant of the 5HTT was herewith highly overrepresented in this subset $(\mathrm{p}<0.001$; table 3$)$. Overall, patients with the L-allelic variant of the 5HTT tended to have higher pulmonary artery pressure (fig. 3) and vascular resistance. With mean mPAPs of $33 \pm 6,29 \pm 2$ and $23 \pm 2 \mathrm{~mm} \mathrm{Hg}(95 \%$ confidence intervals 19-26, 25-33 and 21-47 mm Hg, respectively) for the LL, LS and SS genotypes, respectively, our results were in close accordance with the study of Eddahibi et al. [7], which found mPAPs of $33 \pm 6,29 \pm 2$ and $23 \pm 2 \mathrm{~mm} \mathrm{Hg}$, respectively, in their French collective $(n=67)$. However, our study did not reach statistical significance due to the smaller sample size $(n=49)$. Retrospective power calculation revealed that for significance we would have needed a sample size of 48 (actually 41) and 30 (actually 21) to detect the presently found mPAP differences of 6 and $12 \mathrm{~mm} \mathrm{Hg}$, respectively, between the SS and LS and SS and LL allelic groups, respectively. If looking at the MPAP difference between the SS allele carriers versus carriers of any L allele $(30 \pm 5 \mathrm{~mm}$ $\mathrm{Hg})$, the difference just failed statistical significance ( $\mathrm{p}=$ 0.057). Conversely, patients homozygote for the S-allelic variant had significantly more severe airway obstruction compared with patients carrying the L allele $(\mathrm{p}=0.04)$. There were no other significant differences of any investigated allele variant between COPD patients with and without $\mathrm{PH}$, and none of the measured parameters differed according to any investigated genotype.

\section{Discussion}

In this study we confirm that even in a selected COPD collective scheduled for RHC, $\mathrm{PH}$ is usually relatively mild, only weakly related to hypoxemia and not related to the degree of airway obstruction [5]. However, similar to others we found that a subgroup of COPD patients (12\%) presents with out-of-proportion elevated pulmonary artery pressure $(>40 \mathrm{~mm} \mathrm{Hg})$ similar to the features seen in (idiopathic) PAH $[1,5,6,24]$. In this group, we found a marked overrepresentation of the 5HTT long allelic variant (L). Hence, our data corroborate the findings of Eddahibi et al. [7] that the homozygote LL genotype of $5 \mathrm{HTT}$ is associated with $\mathrm{PH}$ in COPD patients, suggesting a role of the serotonin system in the pathogenesis of $\mathrm{PH}$ in COPD.

The pathogenesis behind $\mathrm{PH}$ in COPD is incompletely understood. However, particularly in the development of out-of-proportion $\mathrm{PH}$, genetic variants may play a role. Germline mutations in the bone morphogenetic protein receptor 2 play an important pathogenetic role in familial and sporadic, but not in other forms of $\mathrm{PAH}$, such as those associated with HIV infection or scleroderma [25, 26]. However, bone morphogenetic protein receptor 2 mutations have not been studied in COPD-PH so far. Eddahibi et al. [7] showed an association of the long allelic variant of the 5HTT with the degree of $\mathrm{PH}$ in hypoxic COPD patients. Consistently, we found an increased frequency of the $\mathrm{L}$ allele in COPD patients with $\mathrm{PH}$ in our cohort. Strikingly, the L-allelic variant was markedly overrepresented in the 6 patients with out-of-proportion $\mathrm{PH}$. In accordance, patients with the L-allelic variant had higher mPAPs and PVRs compared to patients with the $S$ variant (table 3; fig. 3). These findings support a pathogenetic role of the serotonin system in the development of $\mathrm{PH}$ in COPD and indicate the need for further studies in this field. 5HTT has been shown to be a key determinator of pulmonary vessel remodeling by mediating proliferation of pulmonary artery smooth muscle cells, directly related to 5HTT gene expression [27-30]. Cells homozygous for the L-allelic variant have been shown to express 2 -fold more 5HTT RNA compared to cells carrying the $\mathrm{S}$-allelic variant. This difference was even more pronounced under hypoxic conditions. This may explain why the 5HTT polymorphism seems only related to $\mathrm{PH}$ in COPD, a disorder closely associated with hypoxemia, while there does not seem to be a relation with other forms of $\mathrm{PH}[8,31]$. In line with a previous study [7], we also found more severe airway obstruction in patients homozygous for the $\mathrm{S}$-allelic variant. One speculative explanation for this difference might be that patients with the L-allelic variant become symptomatic due to higher pulmonary artery pressure earlier in the disease, when they have less airflow limitation. Given the prognostic impact of $\mathrm{PH}$ in $\mathrm{COPD}$, early identification and especially further studies assessing therapeutic opportunities for $\mathrm{PH}$ in COPD are mandatory. One approach could be to investigate the effect of 5HTT inhibitors on $\mathrm{PH}$ in selected COPD patients, as they have been shown to inhibit the in vitro proliferative response of smooth muscle cells when given orally to experimental animals exposed to hypoxia $[29,32]$. 
Agonists of the 5HT2 receptors, such as fenfluramine, are associated with an increased risk for $\mathrm{PH}$ [33], and 5HTR 2 receptor antagonists are currently investigated as treatment options in $\mathrm{PH}[34,35]$.

Although usually mild, $\mathrm{PH}$ is the most important terminator of outcome in COPD [36]. It has been shown that $\mathrm{PH}$ in COPD is only moderately linked to hypoxemia and even less to the degree of airflow obstruction. Therefore, genetics, environmental and comorbid factors must play a pathogenetic role $[3,4,36,37]$. Severe $\mathrm{PH}$ in COPD is rare and may indicate a clinically and pathogenetically distinct disease $[6,18]$. In our collective, mild $\mathrm{PH}$ was present in up to $84 \%$ of patients considering a threshold $\mathrm{mPAP} \geq 20 \mathrm{~mm} \mathrm{Hg}$ (as widely used in the respiratory literature) $[3,4,38]$, and in $55 \%$ if defined by the WHO ( $\mathrm{mPAP} \geq 25 \mathrm{~mm} \mathrm{Hg}$ ). This is in line with previously published articles $[18,39]$. However, in analogy to previous reports [18], severe $\mathrm{PH}(\mathrm{mPAP}>40 \mathrm{~mm} \mathrm{Hg}$ ) was found in $12 \%$ of the present COPD cohort. Whether this out-ofproportion $\mathrm{PH}$ in COPD reflects a pathogenetically distinct COPD subset and whether this subset might be amenable to specific $\mathrm{PH}$ therapy warrants further studies. It is also important to mention that other reasons for $\mathrm{PH}$ may be found in COPD patients. In our study we excluded $10(27 \%)$ out of totally 37 COPD patients with $\mathrm{PH}$ for comorbid reasons. Many of them suffered from chronic thromboembolic $\mathrm{PH}$, a potentially surgically accessible disease [40], others had diastolic left heart dysfunction and 1 patient was diagnosed with scleroderma. The diagnosis of other $\mathrm{PH}$-associated comorbid conditions in COPD patients is important, as specific therapies for some PH classes may considerably improve the patients' quality of life and prognosis.

The development of PH in COPD is mainly attributed to alveolar hypoxia [4]. In line with previous studies, we found a mild association between hypoxemia and $\mathrm{PH}$ severity $[7,18]$. As for the degree of airway obstruction, the association with $\mathrm{PH}$ severity was even weakly inverse in our collective [7]. This may partly be explained by selection, as we only included COPD patients scheduled for RHC and therefore possibly had more patients with outof-proportion $\mathrm{PH}$, a subset possibly mimicking $\mathrm{PAH}$ [18].

The present study has several limitations. First, we studied a selected COPD population scheduled for RHC. It must therefore be assumed that $\mathrm{PH}$ might be overrepresented in this collective due to selection bias. It could thus be that the clinical and genetic differential characteristics of COPD patients would be different in a more general COPD collective with milder disease. However, as specific therapy for $\mathrm{PH}$ in COPD is currently lacking and as there is no evidence-based study demonstrating the clinical value of RHC in advanced COPD, it would be ethically difficult to search for PH using RHC in a general COPD population outside a proper study protocol. A second limitation is the relatively small sample size. However, for the above mentioned reasons, RHC is not performed very often in COPD patients. Third, we herein investigated only some genetic variants of the serotonin and NO system. It could well be true that other, herein not accounted, genetic variants play a role in COPD-associated $\mathrm{PH}$.

In summary, our study confirms previous results that the long allelic variant of the serotonin transporter is associated with PH in COPD, especially in those with outof-proportion pulmonary artery pressures. Our data support a possible role of the serotonin system in the pathogenesis of COPD-associated $\mathrm{PH}$ and will help to direct future research in the field.

\section{References}

1 Barbera JA, Peinado VI, Santos S: Pulmonary hypertension in chronic obstructive pulmonary disease. Eur Respir J 2003;21: 892-905.

-2 Kessler R, Faller M, Weitzenblum E, Chaouat A, Aykut A, Ducolone A, Ehrhart M, Oswald-Mammosser M: 'Natural history' of pulmonary hypertension in a series of 131 patients with chronic obstructive lung disease. Am J Respir Crit Care Med 2001;164: 219-224.
-3 Scharf SM, Iqbal M, Keller C, Criner G, Lee S, Fessler HE: Hemodynamic characterization of patients with severe emphysema. Am J Respir Crit Care Med 2002;166:314-322.

$\checkmark 4$ Weitzenblum E, Sautegeau A, Ehrhart M, Mammosser M, Hirth C, Roegel E: Longterm course of pulmonary arterial pressure in chronic obstructive pulmonary disease. Am Rev Respir Dis 1984;130:993-998.
5 Chaouat A, Bugnet AS, Kadaoui N, Schott R, Enache I, Ducolone A, Ehrhart M, Kessler R, Weitzenblum E: Severe pulmonary hypertension and chronic obstructive pulmonary disease. Am J Respir Crit Care Med 2005; 172:189-194.

6 Weitzenblum E, Chaouat A: Severe pulmonary hypertension in COPD: is it a distinct disease? Chest 2005;127:1480-1482. 
7 Eddahibi S, Chaouat A, Morrell N, Fadel E, Fuhrman C, Bugnet AS, Dartevelle P, Housset B, Hamon M, Weitzenblum E, Adnot S: Polymorphism of the serotonin transporter gene and pulmonary hypertension in chronic obstructive pulmonary disease. Circulation 2003;108:1839-1844.

-8 Machado RD, Koehler R, Glissmeyer E, Veal C, Suntharalingam J, Kim M, Carlquist J, Town M, Elliott CG, Hoeper M, Fijalkowska A, Kurzyna M, Thomson JR, Gibbs SR, Wilkins MR, Seeger W, Morrell NW, Gruenig E, Trembath RC, Janssen B: Genetic association of the serotonin transporter in pulmonary arterial hypertension. Am J Respir Crit Care Med 2006;173:793-797.

$>9$ Liolitsa D, Powell JF, Prince M, Lovestone S: Association study of the 5-HT(2A) receptor gene polymorphism, T102C and essential hypertension. J Hum Hypertens 2001;15: 335-339.

- 10 Yamada S, Akita H, Kanazawa K, Ishida T, Hirata K, Ito K, Kawashima S, Yokoyama M: T102C polymorphism of the serotonin (5HT) $2 \mathrm{~A}$ receptor gene in patients with nonfatal acute myocardial infarction. Atherosclerosis 2000;150:143-148.

-11 Humbert M, Morrell NW, Archer SL, Stenmark KR, MacLean MR, Lang IM, Christman BW, Weir EK, Eickelberg O, Voelkel NF, Rabinovitch M: Cellular and molecular pathobiology of pulmonary arterial hypertension. J Am Coll Cardiol 2004;43:13S24S.

-12 Droma Y, Hanaoka M, Ota M, Katsuyama Y, Koizumi T, Fujimoto K, Kobayashi T, Kubo $\mathrm{K}$ : Positive association of the endothelial nitric oxide synthase gene polymorphisms with high-altitude pulmonary edema. Circulation 2002;106:826-830.

13 Ahsan A, Mohd G, Norboo T, Baig MA, Pasha MA: Heterozygotes of NOS3 polymorphisms contribute to reduced nitrogen oxides in high-altitude pulmonary edema. Chest 2006;130:1511-1519.

- 14 Smith EM, Baillie JK, Thompson AA, Irving JB, Porteous D, Webb DJ: Endothelial nitric oxide synthase polymorphisms do not influence pulmonary artery systolic pressure at altitude. High Alt Med Biol 2006;7:221-227.

15 Standards for the diagnosis and care of patients with chronic obstructive pulmonary disease. American Thoracic Society. Am J Respir Crit Care Med 1995;152:S77-S121.

16 BTS guidelines for the management of chronic obstructive pulmonary disease. The COPD Guidelines Group of the Standards of Care Committee of the BTS. Thorax 1997; 52(suppl 5):S1-S28.

17 Siafakas NM, Vermeire P, Pride NB, Paoletti P, Gibson J, Howard P, Yernault JC, Decramer M, Higenbottam T, Postma DS, et al: Optimal assessment and management of chronic obstructive pulmonary disease (COPD). The European Respiratory Society Task Force. Eur Respir J 1995;8:1398-1420.
8 Thabut G, Dauriat G, Stern JB, Logeart D, Levy A, Marrash-Chahla R, Mal H: Pulmonary hemodynamics in advanced COPD candidates for lung volume reduction surgery or lung transplantation. Chest 2005; 127:1531-1536.

19 Chaouat A, Naeije R, Weitzenblum E: Pulmonary hypertension in COPD. Eur Respir J 2008;32:1371-1385.

20 Hersberger M, Marti-Jaun J, Rentsch K, Hanseler E: Rapid detection of the CYP2D6*3, CYP2D6*4, and CYP2D6*6 alleles by tetra-primer PCR and of the CYP2D6* 5 allele by multiplex long PCR. Clin Chem 2000;46:1072-1077.

21 Muntwyler J, Marti-Jaun J, Luscher TF, Hanseler E, Hersberger M: The Asp298 but not the C-786 genotype of the endothelial nitric oxide synthase is reduced with age in healthy Swiss men. Clin Chem Lab Med 2005;43: 971-973.

22 Wang XL, Sim AS, Badenhop RF, McCredie RM, Wilcken DE: A smoking-dependent risk of coronary artery disease associated with a polymorphism of the endothelial nitric oxide synthase gene. Nat Med 1996;2:41-45.

-23 Ruegg C, Hersberger M, Wusk B, Rentsch K, Kullak-Ublick GA, von Eckardstein A, Maly FE: Detection of the Arg702Trp, Gly908Arg and Leu1007fsinsC polymorphisms of the NOD2/CARD15 gene by real-time PCR with melting curve analysis. Clin Chem Lab Med 2004;42:494-498.

24 McNeil K: Assessment of patients with pulmonary hypertension. Respiration 2008; 76 : 373-374.

25 Morse J, Barst R, Horn E, Cuervo N, Deng $\mathrm{Z}$, Knowles J: Pulmonary hypertension in scleroderma spectrum of disease: lack of bone morphogenetic protein receptor $2 \mathrm{mu}$ tations. J Rheumatol 2002;29:2379-2381.

26 Morse JH: Genetic studies of pulmonary arterial hypertension. Lupus 2003;12:209212.

27 Eddahibi S, Hanoun N, Lanfumey L, Lesch KP, Raffestin B, Hamon M, Adnot S: Attenuated hypoxic pulmonary hypertension in mice lacking the 5-hydroxytryptamine transporter gene. J Clin Invest 2000;105: 1555-1562.

28 Eddahibi S, Humbert M, Fadel E, Raffestin B, Darmon M, Capron F, Simonneau G, Dartevelle P, Hamon M, Adnot S: Hyperplasia of pulmonary artery smooth muscle cells is causally related to overexpression of the serotonin transporter in primary pulmonary hypertension. Chest 2002;121:97S98S.
29 Eddahibi S, Humbert M, Fadel E, Raffestin B, Darmon M, Capron F, Simonneau G, Dartevelle P, Hamon M, Adnot S: Serotonin transporter overexpression is responsible for pulmonary artery smooth muscle hyperplasia in primary pulmonary hypertension. J Clin Invest 2001;108:1141-1150.

30 Lesch KP, Bengel D, Heils A, Sabol SZ, Greenberg BD, Petri S, Benjamin J, Muller CR, Hamer DH, Murphy DL: Association of anxiety-related traits with a polymorphism in the serotonin transporter gene regulatory region. Science 1996;274:1527-1531.

>31 Koehler R, Olschewski H, Hoeper M, Janssen B, Grunig E: Serotonin transporter gene polymorphism in a cohort of German patients with idiopathic pulmonary arterial hypertension or chronic thromboembolic pulmonary hypertension. Chest 2005;128: 619S

\32 Marcos E, Adnot S, Pham MH, Nosjean A, Raffestin B, Hamon M, Eddahibi S: Serotonin transporter inhibitors protect against hypoxic pulmonary hypertension. Am J Respir Crit Care Med 2003;168:487-493.

-33 Eddahibi S, Adnot S: Anorexigen-induced pulmonary hypertension and the serotonin (5-HT) hypothesis: lessons for the future in pathogenesis. Respir Res 2002;3:9.

34 Wang HL: The serotonin receptor and transporter as potential therapeutic targets for pulmonary hypertension. Curr Opin Investig Drugs 2004;5:963-966.

35 Hironaka E, Hongo M, Sakai A, Mawatari E, Terasawa F, Okumura N, Yamazaki A, Ushiyama Y, Yazaki Y, Kinoshita O: Serotonin receptor antagonist inhibits monocrotalineinduced pulmonary hypertension and prolongs survival in rats. Cardiovasc Res 2003; 60:692-699.

$>36$ Weitzenblum E, Hirth C, Ducolone A, Mirhom R, Rasaholinjanahary J, Ehrhart M: Prognostic value of pulmonary artery pressure in chronic obstructive pulmonary disease. Thorax 1981;36:752-758.

-37 Ulrich S, Nicolls MR, Taraseviciene L, Speich $\mathrm{R}$, Voelkel N: Increased regulatory and decreased CD8+ cytotoxic T cells in the blood of patients with idiopathic pulmonary arterial hypertension. Respiration 2008;75:272280 .

38 Weitzenblum E, Sautegeau A, Ehrhart M, Mammosser M, Pelletier A: Long-term oxygen therapy can reverse the progression of pulmonary hypertension in patients with chronic obstructive pulmonary disease. Am Rev Respir Dis 1985;131:493-498.

-39 Vizza CD, Lynch JP, Ochoa LL, Richardson G, Trulock EP: Right and left ventricular dysfunction in patients with severe pulmonary disease. Chest 1998;113:576-583.

40 Dartevelle P, Fadel E, Mussot S, Chapelier A, Herve $\mathrm{P}$, de Perrot M, Cerrina J, Ladurie FL, Lehouerou D, Humbert M, Sitbon O, Simonneau G: Chronic thromboembolic pulmonary hypertension. Eur Respir J 2004;23: 637-648. 